\title{
Zulu Language
}

National Cancer Institute

\section{Source}

National Cancer Institute. Zulu Language. NCI Thesaurus. Code C154209.

A Niger-Congo Bantu language spoken by the Zulu people of South Africa. 